Review

\title{
The Use of Palladium on Magnetic Support as Catalyst for Suzuki-Miyaura Cross-Coupling Reactions
}

\author{
Magne O. Sydnes \\ Faculty of Science and Technology, University of Stavanger, NO-4036 Stavanger, Norway; \\ magne.o.sydnes@uis.no; Tel.: +47-5183-1761 \\ Academic Editor: Ioannis D. Kostas \\ Received: 6 December 2016; Accepted: 19 January 2017; Published: 23 January 2017
}

\begin{abstract}
The development of new solid supports for palladium has received a lot of interest lately. These catalysts have been tested in a range of cross-coupling reactions, such as Suzuki-Miyaura, Mizoroki-Heck, and Sonogashira cross-coupling reactions, with good outcomes. Attaching the catalyst to a solid support simplifies the operations required in order to isolate and recycle the catalyst after a reaction has completed. Palladium on solid supports made of magnetic materials is particularly interesting since such catalysts can be removed very simply by utilizing an external magnet, which withholds the catalyst in the reaction vessel. This review will showcase some of the latest magnetic solid supports for palladium and highlight these catalysts' performance in Suzuki-Miyaura cross-coupling reactions.
\end{abstract}

Keywords: palladium; magnetic support; Suzuki-Miyaura cross-coupling; catalyst recycling

\section{Introduction}

Since the discovery of the Suzuki-Miyaura cross-coupling reaction in 1979 (Scheme 1) [1-3], it has become one of the most utilized cross-coupling reactions both in industrial and academic research laboratories [3-7]. For the development of this reaction Suzuki was awarded the 2010 Nobel prize in chemistry, together with Negishi and Heck, the chemists behind the Negish coupling and Heck coupling, respectively [8-10]. Since the early reports by Suzuki and Miyaura on the cross-coupling reaction a tremendous development has taken place in terms of substrate flexibility and reaction conditions. A range of different catalysts and conditions are now available for the successful cross-coupling of halides, triflates, $\mathrm{O}$-tosylates, and diazonium salts upon reaction with boronic acid, boronates, and trifluoroborates [3,7,11-15].

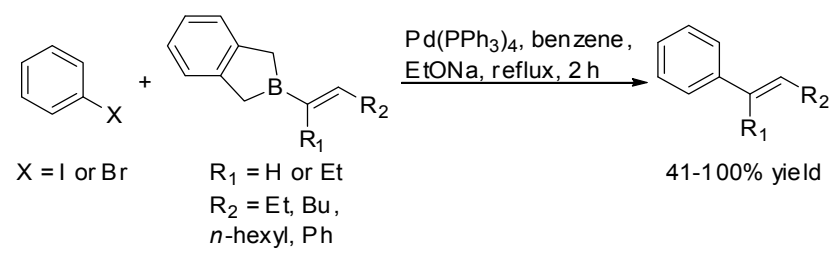

Scheme 1. Reaction conditions and substrates used in the first reported Suzuki-Miyaura cross-couplings [1].

Homogeneous palladium catalyst systems have, by far, been the most dominating catalysts utilized for this cross-coupling reaction [7]. In addition to the catalyst many reactions also require the addition of ligands in order to either promote a reaction that does not work or improve yields of sluggish reactions. However, lately there has been a growing interest for the use of heterogeneous catalysts for the Suzuki-Miyaura cross-coupling reaction, which can be seen by the increasing number 
of publications on the topic [16-18]. The growing interest is due to the many possibilities that heterogeneous catalysts open up for recovery and recycling of the metal catalyst.

Palladium on charcoal (Pd/C) was used for the first time as a catalyst for the Suzuki-Miyaura cross-coupling in 1994 [19]. The work by Marck et al. marked the beginning of the use of heterogeneous catalysts systems in this particular cross-coupling reaction. Since then it has been applied to an increasing number of reactions making $\mathrm{Pd} / \mathrm{C}$ one of the most utilized catalyst supports for heterogeneous Suzuki-Miyaura cross-coupling reactions. Several review articles have discussed their use in cross-coupling reactions and Suzuki-Miyaura cross-couplings in particular [20-23]. Lately graphene has also been taken into use as a catalyst support for palladium [24], in addition to graphite oxide [25]. Although graphene, similarly to charcoal, is pure carbon, it adds new properties to the catalyst that are not seen with charcoal as the catalyst support.

Other types of carbon-containing materials are also frequently used as support for palladium nanoparticles (NPs). A good overview of naturally-occurring biopolymers used as catalyst supports was presented by Kumbhar and Salunkhe in 2015 [26]. For example, palladium on various types of tea leaves [27], cellulose [28,29], chitosan [30,31], pyrolysed whole plants [32], cotton [33], and filter paper [33] have been used with success in Suzuki-Miyaura cross-coupling reactions. Palladium on synthetic polymer films has also been utilized with very promising results both in view of the conversion, but also in terms of recyclability [34-36]. Chalcogenide nanoparticles are a support material that has been used as a catalyst support [37]. In addition, metal-organic frameworks (MOF) have been used in order to support palladium used for cross-coupling reactions. A recent review by Dhakshinamoorthy et al. describes the current status of this type of support materials for palladium [38]. The use of MOF as a catalyst support is also briefly discussed in a review describing recent advances and applications in boron chemistry [39].

Although many of the catalyst supports mentioned briefly above are suitable for recycling there are very few of them that can be easily recycled. One very good example of a catalyst that is easy to recycle is palladium on a polymer film support, the so called dip catalyst [34,35]. The polymer film with the catalyst can be easily added to the reaction mixture and when the reaction has reached completion the film can simply be removed from the reaction flask. A quick washing procedure then makes the catalyst ready for the next reaction.

The preparation of palladium on magnetic supports, predominately $\mathrm{Fe}_{3} \mathrm{O}_{4}$, with a range of different attachment strategies, has gained a lot of attention lately. The magnetic support makes it easy to isolate the catalyst by withholding it in the reaction flask by the use of an external magnet. The reaction mixture can then be removed and the catalyst can easily be washed preparing it for the next reaction. Naturally, catalysts that perform well over many runs with minimum loss of product yield are preferable. This review will discuss the developments made for the use of magnetic-supported catalysts for the Suzuki-Miyaura cross-coupling reaction since late 2013. For literature discussing the topic prior to 2013 the reader is referred to several reviews describing the topic $[16,20,21]$.

\section{Palladium on Magnetically Supports}

Amongst the solid supports utilized for palladium, and other catalytic metals for that matter, magnetic particles have become quite popular. This is predominantly due to their easy removal from the reaction mixture after the reaction has reached completion [16]. Due to the magnetic beads, it is simple to apply an external magnetic field and decant the reaction mixture off (Figure 1). The catalyst can then be washed and used again in the next cross-coupling reaction. The ability for the various catalysts to tolerate many rounds of recycling then becomes an important parameter to consider. 


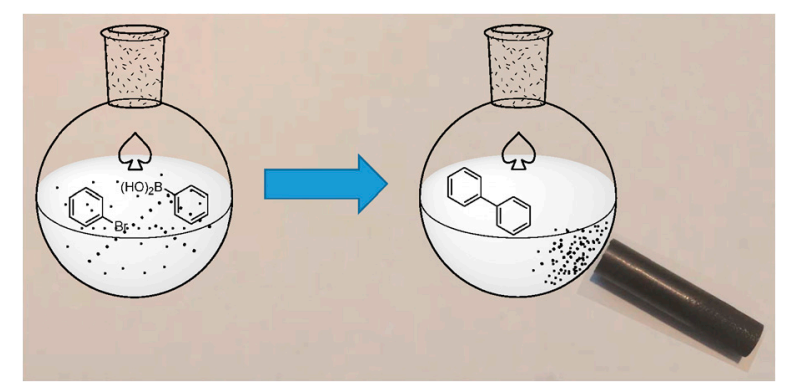

Figure 1. Application of an external magnetic field that collects the catalyst and withholds it in the reaction flask making it possible to decant the product mixture. The catalyst can then be washed and used in another cross-coupling reaction immediately afterwards.

\subsection{The Magnetic Particle}

A range of metals, $\mathrm{Fe}, \mathrm{Co}$, and $\mathrm{Ni}$; alloys, $\mathrm{FePt}$ and $\mathrm{CoPt}$; and ferrites, $\mathrm{CoFe}_{2} \mathrm{O}_{4}, \mathrm{MnFe}_{2} \mathrm{O}_{4}, \mathrm{CuFe}_{2} \mathrm{O}_{4}$, $\mathrm{CoFe}_{2} \mathrm{O}_{4}$, and $\mathrm{ZnFe}_{2} \mathrm{O}_{4}$, can be formed into magnetic nanoparticles (NPs) [40]. However, the majority of magnetic retractable NP catalysts in use are metal oxides, such as iron(II) oxide (FeO), magnetite $\left(\mathrm{Fe}_{3} \mathrm{O}_{4}\right)$, and maghemite $\left(\gamma-\mathrm{Fe}_{2} \mathrm{O}_{3}\right)$, due to their ease of formation. In the Suzuki-Miyaura cross-coupling the majority of catalyst systems on magnetic NPs are based on $\mathrm{Fe}_{3} \mathrm{O}_{4}$. Another very interesting feature with iron oxides $\left(\mathrm{Fe}_{\mathrm{x}} \mathrm{O}_{\mathrm{y}}\right)$ is that they have been found to facilitate the reduction of oxidized palladium species onto the iron oxide in Suzuki-Miyaura cross-couplings and by such means capture leached palladium [41]. Palladium can be deposited directly on the iron oxide NP surface [41], or a thin coating can be applied often in the form of $\mathrm{SiO}_{2}$ (Figure 2a), which functions as a handle for attaching organic ligands that hold palladium in place (Figure 2b). Furthermore, polystyrene-coated iron nanoparticles have also been utilized with good outcome [42].

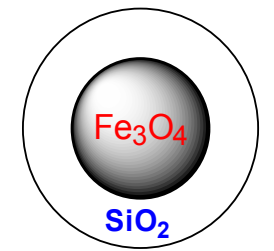

a

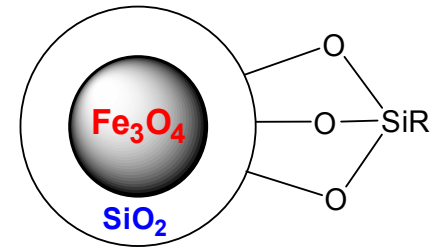

b

Figure 2. (a) $\mathrm{Fe}_{3} \mathrm{O}_{4}$ coated with $\mathrm{SiO}_{2}$ is the predominant magnetic particle used in these catalyst systems; and (b) the finer details of how the ligand that holds palladium in place is attached to the magnetic particle.

\subsection{Palladium Deposited Directly onto the Iron Oxide Nanoparticle}

As just described in Section 2.1, one strategy for generating a magnetic retractable catalyst is to deposit the palladium directly onto the iron oxide nanoparticle. Several good examples of this strategy used for the Suzuki-Miyaura cross-coupling reaction have been reported over the last three years (Table 1).

In the work by Sun et al. $\mathrm{Fe}_{3} \mathrm{O}_{4} @ \mathrm{C}-\mathrm{Pd} @ m \mathrm{SiO}_{2}$ was used in order to give the corresponding biaryls in good yield (Table 1, Entry 1) [43]. However, when 3-pyridyl boronic acid and 2-thiophenyl boronic acid was utilized the yields dropped to $19 \%$ and $38 \%$, respectively. Park and co-workers obtained good, stable yields with $\mathrm{Pd} @ \mathrm{Fe}_{3} \mathrm{O}_{4} @ \mathrm{C}$ as a catalyst (Table 1, Entry 2) [44]. The catalyst gave stable yields $>99 \%$ (for $\mathrm{PhX}$ with $\mathrm{PhB}(\mathrm{OH})_{2}$ ) over four rounds of recycling. Li et al. obtained predominantly higher yields than $90 \%$ for $\mathrm{X}=\mathrm{Br}$ and I (Table 1, Entry 3) [45]. However, when $\mathrm{X}=\mathrm{Cl}$ the yields dropped dramatically to around 50\%. The catalyst, namely $\mathrm{Fe}_{3} \mathrm{O}_{4} @ \mathrm{C}-\mathrm{Pd} @ m \mathrm{CeO}_{2}$, was recycled 10 times, which resulted in the yields dropping from $99 \%$ to $90 \%$ for the cross-coupling of 4-iodoanisole with phenylboronic acid. 
Table 1. Use of palladium directly deposited onto iron oxide nanoparticles as a catalyst for Suzuki-Miyaura cross-coupling.

\begin{tabular}{|c|c|c|c|c|c|c|c|}
\hline Entry & Catalyst & Conditions & $\mathbf{R}$ & $\operatorname{ArB}(\mathrm{OH})_{2}$ & $x$ & Yield & Reference \\
\hline 1 & $\mathrm{Fe}_{3} \mathrm{O}_{4} @ \mathrm{C}-\mathrm{Pd} @ m \mathrm{SiO}_{2}$ & $\begin{array}{l}\mathrm{ArB}(\mathrm{OH})_{2} \text { (1.5 equiv.), } \mathrm{ArX}(1.0 \text { equiv.), } \\
\mathrm{Cat.}(1.5 \mathrm{~mol} \% \mathrm{Pd}), \mathrm{K}_{2} \mathrm{CO}_{3}, i \mathrm{PrOH}, \\
70^{\circ} \mathrm{C}, 6 \mathrm{~h}\end{array}$ & $\mathrm{H}, 4-\mathrm{OMe}, 4-\mathrm{NO}_{2}$, 4-COMe & $\begin{array}{l}\text { Ph, 3-pyridyl, 2-thiophenyl, } \\
\text { 1-naphthalene }\end{array}$ & $\mathrm{I}$ & $\begin{array}{l}73 \%-99 \% \text { (for } \mathrm{Ar}=\mathrm{Ph}) \\
19 \%-38 \% \text { (for the heterocycles) }\end{array}$ & [43] \\
\hline 2 & $\mathrm{Pd} @ \mathrm{Fe}_{3} \mathrm{O}_{4} @ \mathrm{C}$ & $\begin{array}{l}\mathrm{ArB}(\mathrm{OH})_{2}(1.2 \text { equiv.), } \mathrm{ArX}(1.0 \text { equiv.), } \\
\mathrm{Cat.}(1.0 \mathrm{~mol} \%), \mathrm{K}_{2} \mathrm{CO}_{3}, \mathrm{DMF} / \mathrm{H}_{2} \mathrm{O} 4: 1, \\
100{ }^{\circ} \mathrm{C}, 4 \mathrm{~h}\end{array}$ & $\begin{array}{l}\text { H, 4-F, 4-OMe, 2-Me, } \\
\text { 4-COMe, 2-COMe }\end{array}$ & $\begin{array}{l}\mathrm{Ph}(\text { for all } \mathrm{X}), 4-\mathrm{Me}-\mathrm{Ph}, \\
4-\mathrm{CF}_{3}-\mathrm{Ph}\end{array}$ & $\mathrm{Cl}, \mathrm{Br}, \mathrm{OTf}$ & $\begin{array}{l}>99 \% \text { (for } \mathrm{PhX} \text { with } \mathrm{Ar}=\mathrm{Ph}) \\
45 \%-99 \%\end{array}$ & [44] \\
\hline 3 & $\mathrm{Fe}_{3} \mathrm{O}_{4} @ \mathrm{C}-\mathrm{Pd} @ m \mathrm{CeO}_{2}$ & $\begin{array}{l}\mathrm{ArB}(\mathrm{OH})_{2}(1.2 \mathrm{mmol}), \mathrm{ArX}(1.0 \mathrm{mmol}) \\
\mathrm{Cat.}(\mathrm{Pd} 3.05 \mathrm{wt} \%), \mathrm{K}_{2} \mathrm{CO}_{3}, \\
\text { EtOH } / \mathrm{H}_{2} \mathrm{O}(1: 1), 80{ }^{\circ} \mathrm{C}, 3 \mathrm{~h}\end{array}$ & $\begin{array}{l}\mathrm{H}, \mathrm{OMe}, \mathrm{OEt}, \mathrm{OCF}_{3}, \mathrm{OH}, \\
\mathrm{NH}_{2}, \mathrm{Me}\end{array}$ & $\begin{array}{l}\mathrm{Ph}, \text { 3-MePh, 4-MePh, 4-F, } \\
\text { 4-OMe, 2-naphthyl }\end{array}$ & $\mathrm{Cl}, \mathrm{Br}, \mathrm{I}$ & $\begin{array}{l}68 \%-99 \%(\mathrm{X}=\mathrm{Br} \text { and } \mathrm{I}) \\
50 \%-58 \%(\mathrm{X}=\mathrm{Cl})\end{array}$ & [45] \\
\hline 4 & $\mathrm{Fe}_{3} \mathrm{O}_{4} @ \mathrm{Pd}-\mathrm{OA}^{\mathrm{a}}$ & $\begin{array}{l}\mathrm{ArB}(\mathrm{OH})_{2}(1.5 \text { equiv.), } \mathrm{ArX} \text { (1 equiv.), } \\
\mathrm{K}_{3} \mathrm{PO}_{4}, \mathrm{DMF}, 115^{\circ} \mathrm{C}, 5 \mathrm{~h}\end{array}$ & 4-OMe & $\mathrm{Ph}, 4-\mathrm{FPh}$ & $\mathrm{I}$ & $80 \%-94 \%{ }^{b}$ & [46] \\
\hline 5 & $\mathrm{Pd} @ \mathrm{Fe}_{3} \mathrm{O}_{4} @ \mathrm{ZnO}$ & $\begin{array}{l}\mathrm{ArB}(\mathrm{OH})_{2}(1 \text { equiv.), } \mathrm{ArX}(1 \text { equiv.), } \\
\mathrm{Cat} .(\mathrm{Pd} 0.1 \mathrm{~mol} \%), \mathrm{K}_{2} \mathrm{CO}_{3}, \mathrm{H}_{2} \mathrm{O}, \\
\left.100{ }^{\circ} \mathrm{C}, 1-3 \mathrm{~h} \text { (for } \mathrm{X}=\mathrm{Br}, \mathrm{I}\right), 7-14 \mathrm{~h} \\
\text { (for } \mathrm{X}=\mathrm{Cl} \text { ) }\end{array}$ & $\begin{array}{l}\text { 4-Me, 4-COMe, 4-Cl, 4-F, } \\
\text { 4- } \mathrm{NO}_{2}, 4-\mathrm{NH}_{2}, 4-\mathrm{CN} \\
\text { 4-pyridin }\end{array}$ & $\begin{array}{l}\mathrm{Ph}, 2-\mathrm{FPh}, 3-\mathrm{FPh}, 4-\mathrm{FPh} \\
\text { 4-EtPh }\end{array}$ & $\mathrm{Cl}, \mathrm{Br}, \mathrm{I}$ & $\begin{array}{l}70 \%-95 \%(X=B r \text { and } \mathrm{I}) \\
25 \%-53 \%(X=C l)\end{array}$ & [47] \\
\hline 6 & $\mathrm{Fe}_{3} \mathrm{O}_{4} @ \mathrm{SiO}_{2}-\mathrm{Pd} @ m \mathrm{CeO}_{2}$ & $\begin{array}{l}\mathrm{ArB}(\mathrm{OH})_{2}(1.2 \text { equiv.), } \mathrm{ArX}(1 \text { equiv.), } \\
\mathrm{Cat.}(\mathrm{Pd} 0.5 \mathrm{mmol} \%), \mathrm{K}_{2} \mathrm{CO}_{3}, \\
\mathrm{EtOH} / \mathrm{H}_{2} \mathrm{O}(9: 1)(\text { for } \mathrm{Br}, \mathrm{I}), 80^{\circ} \mathrm{C} \text { (for } \\
\left.\mathrm{Br}, \mathrm{I}), \mathrm{DMF} / \mathrm{H}_{2} \mathrm{O}(9: 1), 100{ }^{\circ} \mathrm{C} \text { (for } \mathrm{Cl}\right) \text {, } \\
3 \mathrm{~h}\end{array}$ & $\begin{array}{l}\mathrm{H}, 3-\mathrm{Me}, 4-\mathrm{OMe}, 4-\mathrm{OCF}_{3}, \\
4-\mathrm{COCH}_{3}\end{array}$ & $\begin{array}{l}\mathrm{Ph}, 3-\mathrm{MePh}, 4-\mathrm{MePh}, \\
\text { 4-OMePh, 4-FPh }\end{array}$ & $\mathrm{Cl}, \mathrm{Br}, \mathrm{I}$ & $\begin{array}{l}75 \%-99 \%(X=B r \text { and } \mathrm{I}) \\
68 \%-88 \%(X=C l)\end{array}$ & [48] \\
\hline 7 & $\mathrm{Fe}_{3} \mathrm{O}_{4} @ h-\mathrm{Pd} @ m \mathrm{CeO}_{2}$ & $\begin{array}{l}\mathrm{ArB}(\mathrm{OH})_{2}(1.2 \text { equiv.), } \mathrm{ArX} \text { (1 equiv.), } \\
\mathrm{Cat.}(\mathrm{Pd} 0.5 \mathrm{mmol} \%), \mathrm{K}_{2} \mathrm{CO}_{3}, \\
\mathrm{EtOH} / \mathrm{H}_{2} \mathrm{O}(9: 1)(\text { for } \mathrm{Br}, \mathrm{I}), 80^{\circ} \mathrm{C} \text { (for } \\
\left.\mathrm{Br}, \mathrm{I}), \mathrm{DMF} / \mathrm{H}_{2} \mathrm{O}(9: 1), 100{ }^{\circ} \mathrm{C} \text { (for } \mathrm{Cl}\right) \\
3 \mathrm{~h}\end{array}$ & $\begin{array}{l}\mathrm{H}, 3-\mathrm{Me}, 4-\mathrm{OMe}, 4-\mathrm{OCF}_{3} \\
4-\mathrm{COCH}_{3}\end{array}$ & $\begin{array}{l}\mathrm{Ph}, 3-\mathrm{MePh}, 4-\mathrm{MePh}, \\
\text { 4-OMePh, 4-FPh }\end{array}$ & $\mathrm{Cl}, \mathrm{Br}, \mathrm{I}$ & $\begin{array}{l}82 \%-99 \%(X=B r \text { and } \mathrm{I}) \\
72 \%-92 \%(X=C l)\end{array}$ & [48] \\
\hline 8 & $\begin{array}{c}\text { Pd@Ni@CB } \\
\mathrm{CB}=\text { carbon black }\end{array}$ & $\begin{array}{l}\mathrm{ArB}(\mathrm{OH})_{2}(1.1 \text { equiv.), } \mathrm{ArX} \text { (1 equiv.), } \\
\mathrm{Cat} \text { ( } \mathrm{Pd} 0.1 \mathrm{~mol} \%), \mathrm{K}_{2} \mathrm{CO}_{3}, \\
\left.\mathrm{EtOH} / \mathrm{H}_{2} \mathrm{O}(1: 1), 30^{\circ} \mathrm{C} \text { (for } \mathrm{X}=\mathrm{Br}, \mathrm{I}\right) \\
80^{\circ} \mathrm{C}(\text { for } \mathrm{X}=\mathrm{Cl}), 45 \mathrm{~min}-1.5 \mathrm{~h}\end{array}$ & $\begin{array}{l}\mathrm{H}, 2-\mathrm{NO}_{2}, 3-\mathrm{NO}_{2}, 4-\mathrm{NO}_{2} \\
\text { 2-OMe, 3-OMe, 4-OMe, } \\
\text { 4-Me, 4-OH, 4-CN, 4-CHO }\end{array}$ & $\mathrm{Ph}$ & $\mathrm{Cl}, \mathrm{Br}, \mathrm{I}$ & $\begin{array}{l}79 \%-95 \%(\mathrm{X}=\mathrm{Br} \text { and } \mathrm{I}) \\
5 \%-60 \%(\mathrm{X}=\mathrm{Cl})\end{array}$ & [49] \\
\hline
\end{tabular}

${ }^{a} \mathrm{OA}=$ oleylamine; $^{\mathrm{b}}$ Two examples were reported, $\mathrm{Ar}=\mathrm{Ph}$ gave a yield of $80 \%$ and $\mathrm{Ar}=4$-FPh gave a yield of $94 \%$. 
The work by Strumia and co-workers predominantly focused on the development of the catalyst, however, the two examples of Suzuki-Miyaura cross-coupling reactions reported resulted in very good yields of the desired product (Table 1, Entry 4) [46]. Palladium on $\mathrm{Fe}_{3} \mathrm{O}_{4}-\mathrm{ZnO}$ nanoparticles were prepared by Hosseini-Sarvari et al. (Table 1, Entry 5) [47]. The catalyst system gave good yields for $\mathrm{X}=\mathrm{Br}$ and $\mathrm{I}$, but the yields with $\mathrm{X}=\mathrm{Cl}$ was low $(25 \%-53 \%)$ despite a prolonged reaction time. Ye and co-workers reported the use of two different magnetic palladium supports in their work (Table 1 , Entries 6 and 7) [48]. $\mathrm{Fe}_{3} \mathrm{O}_{4} @ h-\mathrm{Pd} @ m \mathrm{CeO}_{2}$ was the preferable catalyst of choice, also giving good yields for the cross-coupling of aryl chlorides. Palladium on nickel and carbon black was used as a catalyst system by Wang and co-workers (Table 1, Entry 8) [49]. The catalyst gave good to excellent yields for $\mathrm{X}=\mathrm{Br}$ and $\mathrm{I}$, however, when the corresponding chloride was used, the yields dropped significantly. In their recycling experiments it was found that the product yield dropped by $18 \%$ over five runs.

Out of the catalysts presented in this section the work by Park and co-workers showed that the catalyst could be used four times, giving yields consistently at $99 \%$ [44], which is the most promising catalyst system in terms of recycling described in this section. However, in order to establish the full potential of the catalyst it should have been tested over several more cycles. There are several examples of catalysts that perform well over a few rounds of recycling before collapsing.

\subsection{Iron Oxide with Ligands Holding Palladium}

Another strategy, which is more commonly used, is to attach an organic substrate to the magnetic nanoparticle. A range of chelating agents have been attached to magnetic nanoparticles in order to chelate to palladium and, by such means, keep the catalyst attached to the magnetic particle. Several of these catalysts are depicted in Figure 3. All but one catalyst is based on $\mathrm{Fe}_{3} \mathrm{O}_{4}$ nanoparticles with $\gamma \mathrm{Fe}_{2} \mathrm{O}_{3}$ making up the last example. These catalysts have been utilized and put to the test in the Suzuki-Miyaura cross-coupling in addition to other cross-coupling reactions.

\subsection{The Use of Palladium Chelated to Magnetic Nanoparticles}

A general trend seen with all of the catalysts described in Figure 3, and further outlined in Table 2, is that the most reactive cross-coupling partners are the iodides, followed by bromides, with chlorides showing the lowest reactivity. The work by Zhang et al. utilized catalyst $\mathbf{1}$ for the formation of biaryls (Table 2, Entry 1) [50]. The catalyst gave constantly high yields for $\mathrm{X}=\mathrm{Br}$ and I, however, when $\mathrm{X}=\mathrm{Cl}$ the yields dropped dramatically. Somsook and co-workers utilized polyaniline attached to a magnetic nanoparticle in order to catalyze the Suzuki-Miyaura cross-coupling reaction between 1-bromo-4-methylbenzene and a range of aryl boronic acids (Table 2, Entry 2) [51]. The outcome of the reactions generally gave good yields with a few exceptions. Catalyst 2 showed high conversion and very good yields for aryl bromides, aryl iodides, and in the two examples that were performed with 1-chloro-4-nitrobenzene (Table 2, Entry 3) [52]. It would have been very interesting to see how this catalyst would perform in cross-coupling reactions between a broader range of aryl chlorides and more complex boronic acids. The catalyst also showed very good yields through 10 runs with only a $1 \%$ reduction in the isolated yield. Catalyst 3 gave good to excellent yields for aryl chlorides, bromides, and iodides (Table 2, Entry 4) [53]. The catalyst also maintained good catalytic activity over six runs both for cross-coupling of iodobenzene and 1-chloro-4-nitrobenezene with phenyl boronic acid.

$\mathrm{Ma}$ and co-workers prepared catalyst 4 and tested its performance in a range of Suzuki-Miyaura cross-coupling reactions (Table 2, Entry 5) [54]. The catalyst performed very well with aryl bromides and iodides in most cases, except for two examples, which contained a nitro group ortho to the halide. When aryl chlorides were tested under the same reaction conditions the yields dropped dramatically compared to the yields obtained with aryl bromides and iodides. In the work by Ghotbinejad et al. SPION-A-Pd(EDTA) (5) (EDTA = ethylenediaminetetraacetic acid) was used as catalyst under both conventional heating and ultrasound condition. The use of ultrasound reduced the reaction time 
from hours to minutes and generally also resulted in slightly better yields compared with the yields obtained when conventional heating was used (Table 2, Entry 6) [55].
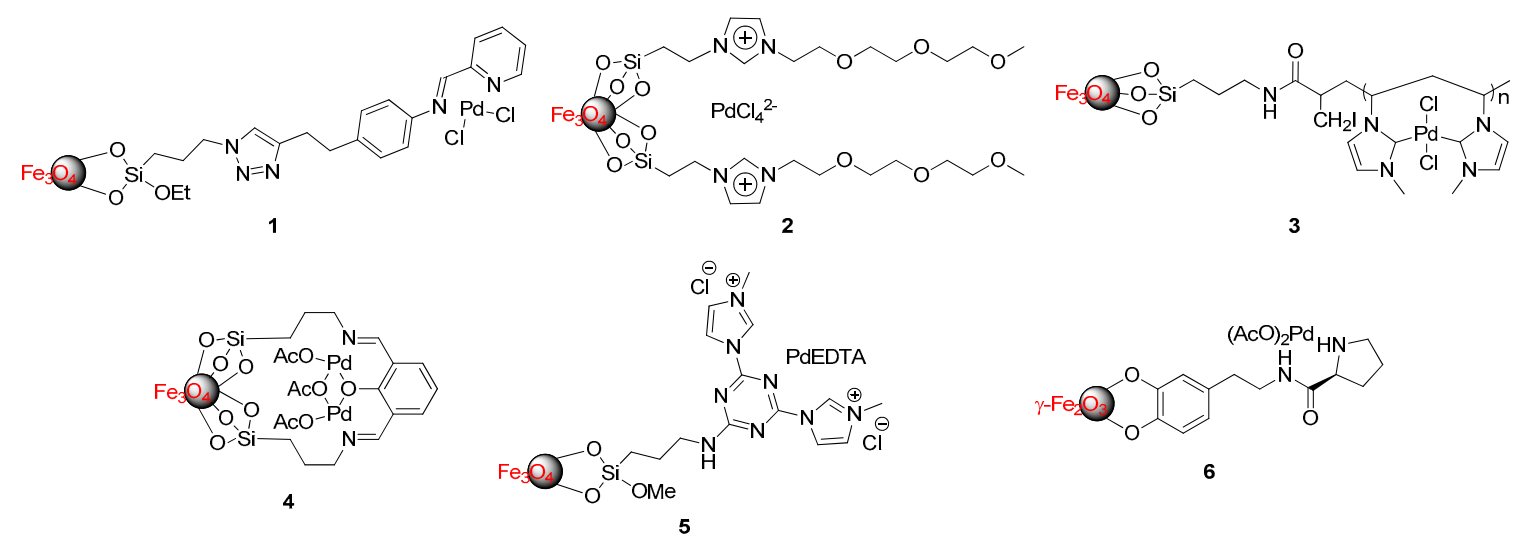

3
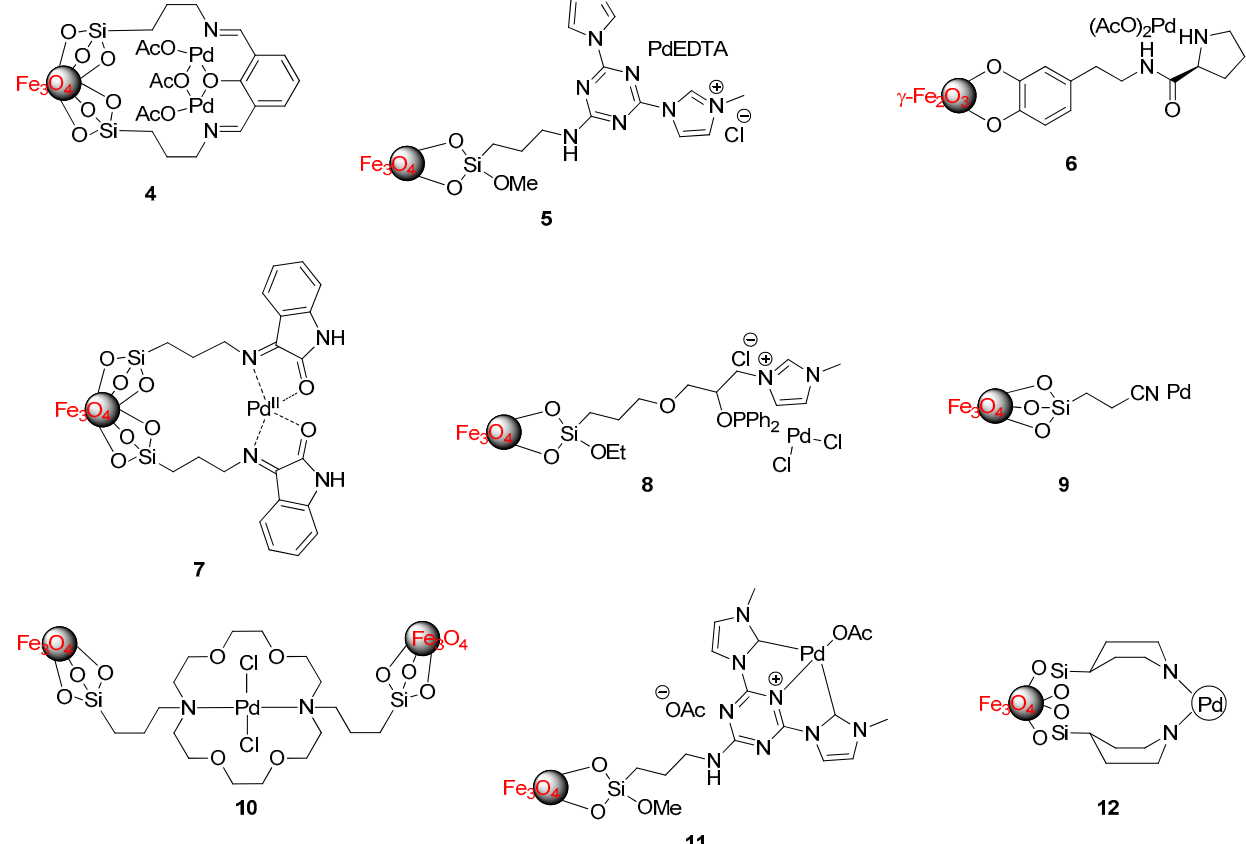

11

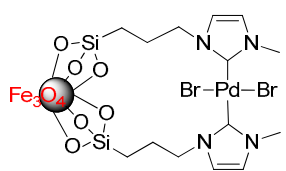

13

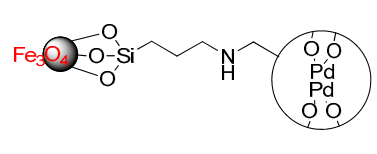

14

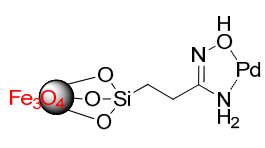

15
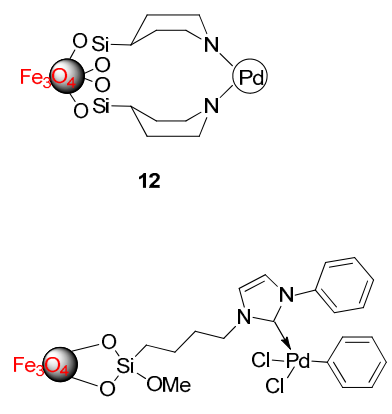

16

Figure 3. The structure of magnetically-supported palladium catalysts used in Suzuki-Miyaura cross-coupling reactions.

Catalyst 6 performed well in all the examples with aryl iodides take for the example where 1-iodo-4-nibrobenzene was cross-coupled with 2-thiophenyl boronic acid (Table 2, Entry 7) [56]. Out of the catalysts presented herein, catalyst 6 is the only one based on $\gamma-\mathrm{Fe}_{2} \mathrm{O}_{3}$ nanoparticles. Upon recycling of this catalyst the yields dropped from $99 \%$ to $90 \%$ over eight runs. Catalyst 7 prepared by Esmaeilpour and Javidi performed well for all three aryl halides with yields ranging from $70 \%-80 \%$ for the aryl chlorides tested (Table 2, Entry 8) [57]. The conditions reported by Biji and co-workers generally gave good yields for all three aryl halides when utilizing catalyst 8 (Table 2, Entry 9) [58]. Although the aryl chlorides only engaged in the cross-coupling reaction under quite forcing conditions $\left(120^{\circ} \mathrm{C}\right)$. Catalyst 9 worked excellently for aryl bromides and aryl iodides, however, the yields were disappointingly low in the examples with aryl chlorides (yields ranging from 20\% to 25\%) (Table 2, Entry 10) [59]. The catalyst prepared by Khakiani could be recycled seven times without significant loss in activity (the yield dropped by $1 \%-2 \%)$. 
Table 2. Use of palladium catalyst chelated to magnetic nanoparticles as catalysts for Suzuki-Miyaura cross-coupling.

\begin{tabular}{|c|c|c|c|c|c|c|c|}
\hline Entry & Catalyst \# & Conditions & $\mathbf{R}$ & $\mathrm{ArB}(\mathrm{OH})_{2}$ & $x$ & Yield & Reference \\
\hline 2 & $\mathrm{Pd} / \mathrm{Poly}(m$-ferrocenyl-aniline & $\begin{array}{l}\mathrm{ArB}(\mathrm{OH})_{2} \text { (1 equiv.), ArX (1 equiv.), Cat. ( } 2.0 \mathrm{~mol} \% \\
\mathrm{Pd}), \mathrm{KOH} \text {, toluene, reflux, } 20 \mathrm{~h}\end{array}$ & 4-Me & $\begin{array}{l}\mathrm{Ph}, 4-\mathrm{MePh}, 3-\mathrm{MePh} \\
\text { 2-MePh, 4-CHOPh }\end{array}$ & $\mathrm{Br}$ & $\begin{array}{l}\text { 67\%-98\% } \\
26 \%\left(\text { for } \mathrm{ArB}(\mathrm{OH})_{2}=4-\mathrm{CHOPh}\right)\end{array}$ & [51] \\
\hline 3 & 2 & $\begin{array}{l}\mathrm{ArB}(\mathrm{OH})_{2}(1.2 \text { equiv.), } \mathrm{ArX}(1 \text { equiv.), } \\
\mathrm{Cat}(0.025 \mathrm{~mol} \% \mathrm{Pd}), \mathrm{K}_{2} \mathrm{CO}_{3}, \mathrm{H}_{2} \mathrm{O}, 60-80^{\circ} \mathrm{C}, 4-15 \mathrm{~h} \\
\text { (for } \mathrm{Br}, \mathrm{I}), 24 \mathrm{~h} \text { (for Cl) }{ }^{\mathrm{a}}\end{array}$ & 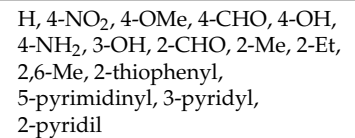 & $\begin{array}{l}\mathrm{Ph}, 4-\mathrm{MePh}, 2-\mathrm{MePh}, \\
\text { 3-pyridyl }\end{array}$ & $\begin{array}{l}\mathrm{Cl}, \mathrm{Br}, \mathrm{I} \\
\text { (three examples } \\
\text { with Cl) }\end{array}$ & $\begin{array}{l}\text { 72\%-quant. }(\mathrm{X}=\mathrm{Br} \text { and } \mathrm{I}) \\
85 \%-96 \%(\mathrm{X}=\mathrm{Cl})\end{array}$ & [52] \\
\hline 4 & 3 & $\begin{array}{l}\mathrm{ArB}(\mathrm{OH})_{2}(1.2 \text { equiv.), } \mathrm{ArX}(1 \text { equiv.), } \\
\mathrm{Cat}\left(\mathrm{O}(0.049 \mathrm{~mol} \% \mathrm{Pd}), \mathrm{K}_{2} \mathrm{CO}_{3}, \mathrm{NMP}, 90^{\circ} \mathrm{C},\right. \\
0.5-2.5 \mathrm{~h} \text { (for } \mathrm{X}=\mathrm{Br} \text { or } \mathrm{I}), 2.5-9 \mathrm{~h} \text { (for } \mathrm{X}=\mathrm{Cl})\end{array}$ & 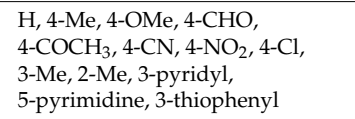 & $\mathrm{Ph}$, & $\mathrm{Cl}, \mathrm{Br}, \mathrm{I}$ & $77 \%-95 \%$ & [53] \\
\hline 5 & 4 & $\begin{array}{l}\text { ArB(OH })_{2}(1.5 \text { equiv.), } \mathrm{ArX}(1 \text { equiv.), } \\
\text { Cat. }(0.5 \mathrm{~mol} \%), \mathrm{K}_{2} \mathrm{CO}_{3}, \mathrm{EtOH}, 80^{\circ} \mathrm{C}, 3-10 \mathrm{~h}\end{array}$ & $\mathrm{H}, 4-\mathrm{Me}, 2-\mathrm{Me}, 4-\mathrm{OH}, 2-\mathrm{NO}_{2}$ & $\mathrm{Ph}, 4-\mathrm{ClPh}(\mathrm{X}=\mathrm{I})$ & $\mathrm{Cl}, \mathrm{Br}, \mathrm{I}$ & $\begin{array}{l}95 \%-99 \%(\mathrm{X}=\mathrm{Br} \text { and } \mathrm{I}) \\
16 \%-64 \%(\mathrm{X}=\mathrm{Cl})\end{array}$ & [54] \\
\hline 6 & 5 & $\begin{array}{l}\mathrm{ArB}(\mathrm{OH})_{2}(1.1 \text { equiv.), } \mathrm{ArX}(1 \text { equiv.), } \\
\text { Cat. (0.003 mol } \% \text { Pd), } \mathrm{K}_{2} \mathrm{CO}_{3}, \mathrm{DMF} / \mathrm{H}_{2} \mathrm{O}(1: 2), \\
70^{\circ} \mathrm{C}, 2-14 \mathrm{~h} \\
\text { Ultrasound applied power } 160 \mathrm{~W}, 30^{\circ} \mathrm{C}, 7-35 \mathrm{~min}\end{array}$ & $\begin{array}{l}\mathrm{H}, 4-\mathrm{Me}, 4-\mathrm{OMe}, 4-\mathrm{CHO}, 4-\mathrm{Ac}, \\
\text { 4-F }\end{array}$ & $\mathrm{Ph}, 4$-OMePh & $\mathrm{Br}, \mathrm{I}$ & $\begin{array}{l}82 \%-93 \%\left(70{ }^{\circ} \mathrm{C}, \text { conventional heating) }\right. \\
87 \%-96 \% \text { (ultrasound conditions) }\end{array}$ & [55] \\
\hline 7 & 6 & $\begin{array}{l}\mathrm{ArB}(\mathrm{OH})_{2}(1.1 \text { equiv. }), \mathrm{ArX}(1 \text { equiv.), } \\
\text { Cat. }(0.1 \mathrm{~mol} \%), \mathrm{Na}_{2} \mathrm{CO}_{3}, \mathrm{EtOH} / \mathrm{H}_{2} \mathrm{O}(1: 1), 80^{\circ} \mathrm{C} \text {, } \\
30 \mathrm{~min}\end{array}$ & $\mathrm{H}, 4-\mathrm{NO}_{2}$ & $\begin{array}{l}\text { 4-COMe, 4-COOEt, } \\
\text { 4-CHO, 4-ethenyl, 4-tolyl, } \\
\text { 4-ethenyl, 2-furanyl, } \\
\text { 2-thiophenyl }\end{array}$ & $\begin{array}{l}\mathrm{Cl}, \mathrm{Br}, \mathrm{I} \text { (only one } \\
\text { example with } \\
\mathrm{X}=\mathrm{Cl} \text { and } \mathrm{Br} \text { ) }\end{array}$ & $60 \%-99 \%$ (for $\mathrm{X}=\mathrm{I}$ ) & [56] \\
\hline 8 & 7 & $\begin{array}{l}\mathrm{ArB}(\mathrm{OH})_{2}(1.2 \text { equiv.), } \mathrm{ArX}(1 \text { equiv.), } \\
\mathrm{Cat}(0.3 \mathrm{~mol} \%), \mathrm{K}_{2} \mathrm{CO}_{3}, \mathrm{NMP}, 100^{\circ} \mathrm{C}, 0.5-4.5 \mathrm{~h} \text { (for } \\
\mathrm{Br}, \mathrm{I}), 4-12 \mathrm{~h} \text { (for Cl) }\end{array}$ & 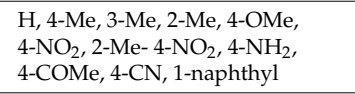 & $\mathrm{Ph}$ & $\mathrm{Cl}, \mathrm{Br}, \mathrm{I}$ & $77 \%-96 \%$ & [57] \\
\hline 9 & 8 & $\begin{array}{l}\mathrm{ArB}(\mathrm{OH})_{2}(1.5 \text { equiv.), } \mathrm{ArX}(1.0 \text { equiv.), } \\
\mathrm{Cat} .\left(0.3 \mathrm{~mol}^{\circ} \%\right), \mathrm{K}_{2} \mathrm{CO}_{3}, \mathrm{EtOH} / \mathrm{H}_{2} \mathrm{O}(1: 1), 30^{\circ} \mathrm{C} \\
\left.(\text { for } \mathrm{X}=\mathrm{I}), 0^{\circ} \mathrm{C} \text { (for } \mathrm{X}=\mathrm{Br}\right), 120{ }^{\circ} \mathrm{C}(\text { for } \mathrm{X}=\mathrm{Cl}), \\
1-24 \mathrm{~h} \text { (for } \mathrm{X}=\mathrm{Br} \text { or } \mathrm{I}), 48 \mathrm{~h}(\text { for } \mathrm{X}=\mathrm{Cl})\end{array}$ & $\begin{array}{l}\text { H, 4-OH, 4-OMe, 4-CHO, 4-NO2, } \\
\text { 4-CN, 4-COMe, 4-biphenyl, } \\
\text { 1-naphthalen, 5-pyrimidine }\end{array}$ & $\begin{array}{l}\mathrm{Ph}, 4-\mathrm{ClPh}, 4-\mathrm{MePh}, \\
\text { 3,5-diFPh, 2-FPh, } \\
\text { 2- } \mathrm{NO}_{2} \mathrm{Ph} \text {, 1-naphthalene }\end{array}$ & $\mathrm{Cl}, \mathrm{Br}, \mathrm{I}$ & $74 \%-98 \%$ & [58] \\
\hline 10 & 9 & $\begin{array}{l}\mathrm{ArB}(\mathrm{OH})_{2}(1.1 \text { equiv.), } \mathrm{ArX}(1 \text { equiv.), Cat. (0.2 } \\
\text { mol } \%), \mathrm{K}_{2} \mathrm{CO}_{3}, \mathrm{EtOH} / \mathrm{H}_{2} \mathrm{O}, 20-25^{\circ} \mathrm{C}, 0.2-6 \mathrm{~h} \text { (for } \\
\mathrm{X}=\mathrm{Br} \text { or I I), 10-12 } \mathrm{h} \text { (for } \mathrm{X}=\mathrm{Cl} \text { ) }\end{array}$ & $\begin{array}{l}\mathrm{H}, 4-\mathrm{Me}_{4} \text { 4-COCH} 3,4-\mathrm{OMe}, 4-\mathrm{Cl} \text {, } \\
\text { 3-NO } 2 \text { - }-\mathrm{CHO} \text { 1-naphthyl, } \\
\text { 2-thienyl }\end{array}$ & $\mathrm{Ph}$ & $\mathrm{Cl}, \mathrm{Br}, \mathrm{I}$ & $\begin{array}{l}88 \%-98 \%(\mathrm{X}=\mathrm{Br} \text { and } \mathrm{I}) \\
20 \%-25 \%(\mathrm{X}=\mathrm{Cl})\end{array}$ & [59] \\
\hline 11 & $\mathrm{Fe}_{3} \mathrm{O}_{4} @ E D T A-\mathrm{PdCl}_{2}$ & $\begin{array}{l}\mathrm{ArB}(\mathrm{OH})_{2}\left(1.1 \text { equiv.), } \operatorname{ArX} \text { (1 equiv.), } \mathrm{K}_{2} \mathrm{CO}_{3},\right. \\
\mathrm{TBAB}^{\mathrm{a}}, \mathrm{H}_{2} \mathrm{O}, 80^{\circ} \mathrm{C}, 2-6 \mathrm{~h}\end{array}$ & $\begin{array}{l}\mathrm{H}, 3-\mathrm{Me}, 3-\mathrm{CF}_{3}, 1-\text {-naphthyl, } \\
\text { 2-thienyl, (for X = Br) } \\
\mathrm{H}, 4 \text {-Me, 4-OMe, 4-NO } \\
\text { (for } \mathrm{X}=\mathrm{I} \text { ) }\end{array}$ & $\mathrm{Ph}$ & $\mathrm{Br}, \mathrm{I}$ & $76 \%-95 \%$ & [60] \\
\hline
\end{tabular}


Table 2. Cont.

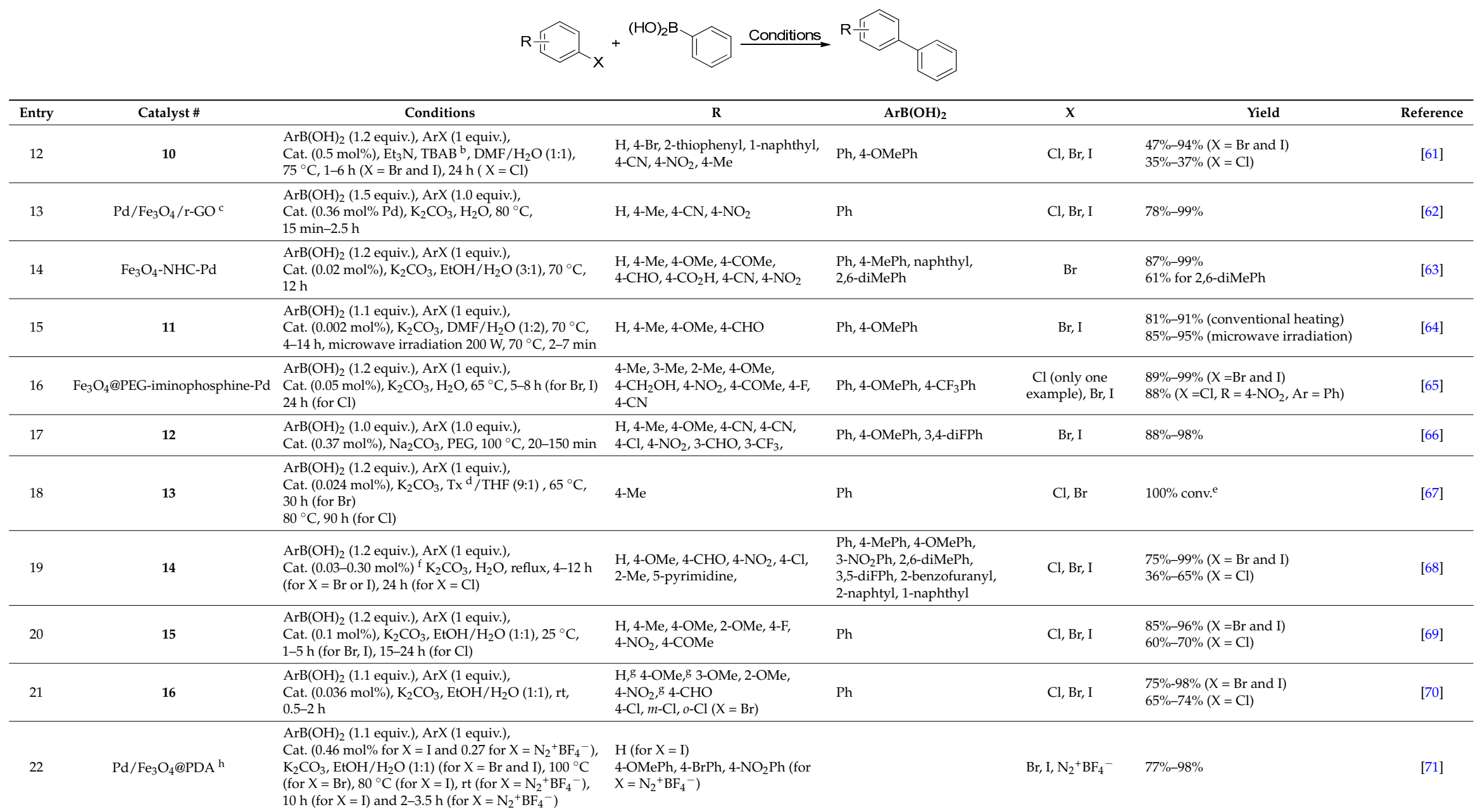

a Reaction conducted at $120{ }^{\circ} \mathrm{C}$ with the addition of 0.5 equiv. of $\mathrm{TBAB}$ and $\mathrm{DMF} / \mathrm{H}_{2} \mathrm{O}(1: 1)$ as solvent; ${ }^{\mathrm{b}} \mathrm{TBAB}=$ tetrabutylammonium bromide; ${ }^{\mathrm{c}} \mathrm{Pd} / \mathrm{Fe} \mathrm{O}_{4} / \mathrm{r}-\mathrm{GO}=$

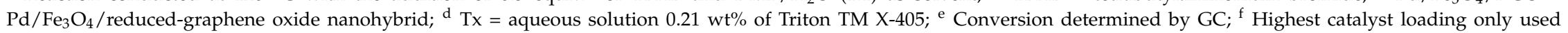
for $\mathrm{X}=\mathrm{Cl}$; ${ }^{\mathrm{g}}$ Reactions conducted with $\mathrm{X}=\mathrm{Cl} ;{ }^{\mathrm{h}} \mathrm{PDA}=$ polydopamine. 
Heydari and co-workers utilized EDTA attached to the magnetic nanoparticle in order to coordinate to the palladium catalyst (Table 2, Entry 11) [60]. The catalyst gave good to excellent yields for the aryl bromides and iodides they tested, however, the yields dropped significantly when the catalyst was recycled (the yield dropped from $90 \%$ in run 1 to $80 \%$ in run 5). Catalyst 10 gave a mix of results, with yields ranging from poor to very good when tested by the Mobaraki group (Table 2, Entry 12) [61]. In particular, the aryl chlorides tested gave very poor yields. Palladium $/ \mathrm{Fe}_{3} \mathrm{O}_{4} /$ reduced-graphene oxide was used by Nasrabadi and co-workers with good outcome to catalyze the Suzuki-Miyaura cross-coupling between a range of aryl chlorides, bromides, and iodides (Table 2, Entry 13) [62]. The catalyst system also maintained its catalytic activity over eight runs with the yield only dropping by $2 \%$ from $97 \%$ in the first run to $95 \%$ in the eighth run.

$\mathrm{Fe}_{3} \mathrm{O}_{4}$-NHC-Pd was used by Wang et al. for a range of aryl bromides with a range of boronic acids (Table 2, Entry 14) [63]. The catalyst system was tested over 21 runs without loss of activity. The yields varied between $93 \%$ and $99 \%$ with $96 \%$ yield in the first run, and $97 \%$ yield in run number 21 . Catalyst $\mathbf{1 1}$ gave very good yields for aryl bromides and iodides both under conventional heating and under microwave conditions (MW) (Table 2, Entry 15) [64]. The great advantage utilizing microwave conditions was that the reactions reached completion in a few minutes compared to hours under conventional conditions. In addition, the yields were slightly higher under MW conditions. The catalyst maintained most of its activity over seven rounds of recycling (yield dropped from $95 \%$ to $93 \%$ ). $\mathrm{Fe}_{3} \mathrm{O}_{4} @$ PEG-iminophosphine-Pd was used as catalyst by Lu and co-workers resulting in good to excellent yields of the desired biaryl system when utilizing all three aryl halides (Table 2, Entry 16) [65]. This catalyst system also showed good perseverance of activity over five runs with only a $2 \%$ drop in the isolated yield. Azadi and Ghorbani-Choghamarani developed catalyst 12, which was put to the test in the Suzuki-Miyaura cross-coupling reaction with good to very good yields for both aryl bromides and aryl iodides (Table 2, Entry 17) [66].

Andrés and co-workers prepared catalyst 13 and tested it in two reactions, namely the cross-coupling of phenyl boronic acid with 1-chloro-4-methylbenzene and 1-bromo-4-methylbenzene (Table 2, Entry 18) [67]. In both cases they reported 100\% conversion as judged by GC analysis. The $\beta$-cyclodextrine-based catalyst system performed well in Suzuki-Miyaura cross-couplings with aryl bromides and aryl iodides, however, the yields dropped dramatically for the corresponding aryl chlorides (Table 2, Entry 19) [68]. Catalyst 14 also showed a dramatic drop in activity over five runs with the isolated yield going down $16 \%$ over the five runs. Catalyst 15 performed very well when utilizing aryl bromides and aryl iodides, however, the yields dropped roughly $30 \%$ when the corresponding aryl chlorides were used (Table 2, Entry 20) [69]. A similar drop in yields was also experienced by Hajipour et al. when they tested catalyst 16 with aryl chlorides (Table 2, Entry 21) [70]. However, with the more active aryl halides, viz. bromide and iodide, the catalyst performed well.

Dubey and Kumar, in addition to aryl bromide and aryl iodide, also tested the corresponding diazonium tetrafluoroborate $\left(\mathrm{N}_{2}{ }^{+} \mathrm{BF}_{4}{ }^{-}\right)$as the coupling partner with boronic acid (Table 2, Entry 22) [71]. This is the only example where this coupling partner has been utilized in combination with a magnetically retrievable catalyst. The reaction time when diazonium tetrafluoroborate was utilized was significantly quicker than the reaction time obtained when $\mathrm{Br}$ and I were utilized. The reaction time was as short as $2-3.5 \mathrm{~h}$ at room temperature. The yields in all examples were generally good ranging from $77 \%$ to $98 \%$.

As mentioned, the trend that is usually seen for aryl chlorides when homogenous catalysts are used is also present in the examples brought forward herein. As just mentioned, the reactivity is significantly lower resulting, in most cases, to much longer reaction times when aryl chlorides are used. The yields are, in most cases, also dramatically lower for aryl chlorides compared to the corresponding iodide or bromide counterpart, although some very nice exceptions can be found in the work of Andrés and co-workers (Table 2, Entry 18) [67]. 


\subsection{Recycling}

As seen in the examples discussed in the forgoing the majority of the catalyst systems give good yields for aryl bromides and aryl iodides, and if the reaction time is prolonged compared to the reaction time used for the aryl bromides and aryl iodides, a number of the aryl chlorides also result in good conversion. However, when it comes to the ability of the various catalysts to perform at the same high level of conversion over multiple cycles, the differences between them becomes obvious. While some catalysts manage to maintain a high level of conversion over numerous rounds of recycling, other catalysts drastically deteriorate after just a few rounds of recycling. In particular, two catalyst systems by Karimi et al. [52] and Lin and co-workers [63] are singled out as better than the rest with the catalysts used by the Lin group being outstanding with its 21 runs without the catalyst losing its activity.

\subsection{Catalyst Leaching}

The active form of the catalyst in heterogeneous catalysis is a topic that has been much debated over the years [72]. Is the reaction catalyzed by the solid catalyst or is it catalyzed by palladium leached out from the heterogeneous catalyst. Very few reports deal with this issue, however, the work by Azadi and Ghorbani-Choghamarani tested this in a very clever way [66]. By removing the catalyst with a magnet when the reaction had proceeded to $50 \%$ conversion, they could evaluate if the reaction proceeded after that point. Their data clearly showed that the reaction stopped after the catalyst was removed, determining that the active catalyst was the heterogeneous palladium catalyst.

\section{Concluding Remarks}

The results presented in this article clearly show that catalysts on magnetic particles are fully able to catalyze the Suzuki-Miyaura cross-coupling reaction in good yields over a reasonable reaction time. However, the substrates demonstrated thus far are relatively simple compared with some of the starting materials used in Suzuki-Miyaura cross-coupling reactions conducted under homogenous conditions. For example, the substrates during such cross-coupling reactions conducted during synthesis of complex natural products or pharmaceuticals are far more complex than the ones utilized during the examples shown herein for heterogeneous catalysis. The use of palladium on magnetic retractable catalyst supports would be of interest in these settings, in particular the latter, where there are strict regulations regarding leftover palladium in the product. In addition, this type of catalyst would become more generally attractive if they were commercially available.

Acknowledgments: The University of Stavanger (UiS), ToppForsk UiS, and the research program Bioactive is gratefully acknowledged for providing funding for my group.

Conflicts of Interest: The author declares no conflict of interest.

\section{References}

1. Miyaura, N.; Suzuki, A. Stereoselective synthesis of arylated (E)-alkenes by the reaction of alk-1-enylboranes with aryl halides in the presence of palladium catalyst. J. Chem. Soc. Chem. Commun. 1979, 19, 135-152. [CrossRef]

2. Miyaura, N.; Yamada, K.; Suzuki, A. A new stereospecific cross-coupling by the palladium-catalyzed reaction of 1-alkenylboranes with 1-alkenyl or 1-alkynyl halides. Tetrahedron Lett. 1979, 20, 3437-3440. [CrossRef]

3. Miyaura, N.; Suzuki, A. Palladium-catalyzed cross-coupling reactions of organoboron compounds. Chem. Rev. 1995, 95, 2457-2483. [CrossRef]

4. Miyaura, N. Cross-coupling reaction of organoboron compounds via base-assisted transmetalation to palladium(II) complexes. J. Organomet. Chem. 2002, 653, 54-57. [CrossRef]

5. Suzuki, A. Cross-coupling reactions via organoboranes. J. Organomet. Chem. 2002, 653, 83-90. [CrossRef]

6. Gildner, P.G.; Colacot, T.J. Reactions of the 21st Century: Two Decades of Innovative Catalyst Design for Palladium-Catalyzed Cross-Couplings. Organometallics 2015, 34, 5497-5508. [CrossRef] 
7. Dobrounig, P.; Trobe, M.; Breinbauer, R. Sequential and iterative Pd-catalyzed cross-coupling reactions in organic synthesis. Monatsh. Chem. 2017, 148, 3-35. [CrossRef]

8. Suzuki, A. Cross-coupling reactions of organoboranes: An easy way to construct C-C Bonds (Nobel Lecture). Angew. Chem. Int. Ed. 2011, 50, 6723-6737. [CrossRef] [PubMed]

9. Negishi, E. Magical power of transition metals: Pas, present, and future (Nobel Lecture). Angew. Chem. Int. Ed. 2011, 50, 6738-6764. [CrossRef] [PubMed]

10. Seechurn, C.C.C.J.; Kitching, M.O.; Colacot, T.J.; Snieckus, V. Palladium-catalyzed cross-coupling: A historical contextual perspective to the 2010 Nobel Prize. Angew. Chem. Int. Ed. 2012, 51, 5062-5085. [CrossRef] [PubMed]

11. Makarasen, A.; Kuse, M.; Nishikawa, T.; Isobe, M. Substituent effect of imino-O-arenesulfonates, a coupling partner in Suzuki-Miyaura reaction for substitution of the pyrazine ring: Study for the synthesis of coelenterazine analogs. Bull. Chem. Soc. Jpn. 2009, 82, 870-878. [CrossRef]

12. Roglans, A.; Pla-Quintana, A.; Moreno-Mañas, M. Diazonium salts as substrates in palladium-catalyzed cross-coupling reactions. Chem. Rev. 2006, 106, 4622-4643. [CrossRef] [PubMed]

13. Taylor, J.G.; Moro, A.V.; Correia, C.R.D. Evolution and Synthetic applications of the Heck-Matsuda reaction: The return of arenediazonium salts to prominence. Eur. J. Org. Chem. 2011, 1403-1428. [CrossRef]

14. Felpin, F.-X.; Nassar-Hardy, L.; Le Callonnec, F.; Fouquet, E. Recent advances in the Heck-Matsuda reaction in heterocyclic chemistry. Tetrahedron 2011, 67, 2815-2831. [CrossRef]

15. Mo, F.; Dong, G.; Zhang, Y.; Wang, J. Recent applications of arene diazonium salts in organic synthesis. Org. Biomol. Chem. 2013, 11, 1582-1593. [CrossRef] [PubMed]

16. Wang, D.; Astruc, D. Fast-growing field of magnetically recyclable nanocatalysts. Chem. Rev. 2014, 114, 6949-6985. [CrossRef] [PubMed]

17. Deraedt, C.; Astruc, D. “Homeopathic" palladium nanoparticle catalysis of cross carbon-carbon coupling reactions. Acc. Chem. Res. 2014, 47, 494-503. [CrossRef] [PubMed]

18. Paul, S.; Islam, M.M.; Islam, S.M. Suzuki-Miyaura reaction by heterogeneously supported Pd in water: Recent studies. RSC Adv. 2015, 5, 42193-42221. [CrossRef]

19. Marck, G.; Villiger, A.; Buchecker, R. Aryl couplings with heterogeneous palladium catalysts. Tetrahedron Lett. 1994, 35, 3277-3280. [CrossRef]

20. Sydnes, M.O. Recent Developments in the use of palladium on solid support in organic synthesis. Curr. Org. Synth. 2011, 8, 881-891. [CrossRef]

21. Sydnes, M.O. Use of nanoparticles as catalysts in organic synthesis-Cross-coupling reactions. Curr. Org. Chem. 2014, 18, 312-326. [CrossRef]

22. Zafar, M.N.; Mohsin, M.A.; Danish, M.; Nazar, M.F.; Murtaza, S. Palladium catalyzed Heck-Mizoroki and Suzuki-Miyaura coupling reactions (review). Russ. J. Coord. Chem. 2014, 40, 781-800. [CrossRef]

23. Felpin, F.-X.; Ayad, T.; Mitra, S. Pd/C: An old catalyst for new applications-Its use for the Suzuki-Miyaura reaction. Eur. J. Chem. 2006, 2679-2690.

24. Fan, X.; Zhang, G.; Zhang, F. Multiple roles of graphene in heterogeneous catalysis. Chem. Soc. Rev. 2015, 44, 3023-3035. [CrossRef] [PubMed]

25. Santra, S.; Hota, P.K.; Bhattacharyya, R.; Bera, P.; Chosh, P.; Mandal, S.K. Palladium nanoparticles on graphite oxide: A recyclable catalyst for the synthesis of biaryl cores. ACS Catal. 2013, 3, 2776-2789. [CrossRef]

26. Kumbhar, A.; Salunkhe, R. Recent advances in biopolymer supported palladium in organic synthesis. Curr. Org. Chem. 2015, 19, 2075-2121. [CrossRef]

27. Lebaschi, S.; Hekmati, M.; Veisi, H. Green synthesis of palladium nanoparticles mediated by black tea leaves (Camellia sinensis) extract: Catalytic activity in the reduction of 4-nitrophenol and Suzuki-Miyaura coupling reaction under ligand-free conditions. J. Colloid Interface Sci. 2017, 485, 223-231. [CrossRef] [PubMed]

28. Xiao, J.; Lu, Z.; Li, Y. Carboxymethylcellulose-supported palladium nanoparticles generated in situ from palladium(II) carboxymethylcellulose: An efficient and reusable catalyst for Suzuki-Miyaura and Mizoroki-Heck reactions. Ind. Eng. Chem. Res. 2015, 54, 790-797. [CrossRef]

29. Chen, F.; Huang, M.; Li, Y. Synthesis of a novel cellulose microencapsulated palladium nanoparticle and its catalytic activities in Suzuki-Miyaura and Mizoroki-Heck reactions. Ind. Eng. Chem. Res. 2014, 53, 8339-8345. [CrossRef] 
30. Naghipor, A.; Fakhri, A. Heterogeneous $\mathrm{Fe}_{3} \mathrm{O}_{4} @$ chitosan-Schiff base Pd nanocatalyst: Fabrication, characterization and application as highly efficient and magnetically-recoverable catalyst for Suzuki-Miyaura and Heck-Mizoroki C-C coupling reactions. Catal. Commun. 2016, 73, 39-45. [CrossRef]

31. Jadhav, S.; Kumbhar, A.; Salunkhe, R. Palladium supported on silica-chitosan hybrid material (Pd-CS@SiO 2$)$ for Suzuki-Miyaura and Mizoroki-Heck cross-coupling reactions. Appl. Organometal. Chem. 2015, 29, 339-345. [CrossRef]

32. Parker, H.L.; Rylott, E.L.; Hunt, A.J.; Dodson, J.R.; Taylor, A.F.; Bruce, N.C.; Clark, J.H. Supported palladium nanoparticles synthesized by living plants as a catalyst for Suzuki-Miyaura reactions. PLoS ONE 2014, 9, e87192. [CrossRef] [PubMed]

33. Nishikata, T.; Tsutsumi, H.; Gao, L.; Kojima, K.; Chikama, K.; Nagashima, H. Adhesive catalyst immobilization of palladium nanoparticles on cotton and filter Paper: Applications to reusable catalysts for sequential catalytic reactions. Adv. Synth. Catal. 2014, 356, 951-960. [CrossRef]

34. Hariprasad, E.; Radhakrishnan, T.P. Palladium nanoparticle-embedded polymer thin film "dip catalyst" for Suzuki-Miyaura reaction. ACS Catal. 2012, 2, 1179-1186. [CrossRef]

35. Rao, V.K.; Radhakrishnan, T.P. Hollow bimetallic nanoparticles generated in situ inside a polymer thin film: fabrication and catalytic application of silver-palladium-poly(vinyl alcohol). J. Mater. Chem. A 2013, 1, 13612-13618. [CrossRef]

36. Oliveira, D.G.M.; Alvarenga, G.; Scheeren, C.W.; Rosa, G.R. Densenvovimento de reator tipo «dip catalyst» para filmes poliméricos contendo nanoparticulas de metais de transição. Quim. Nova 2014, 37, 1401-1403.

37. Kumar, A.; Rao, G.K.; Kumar, S.; Singh, A.K. Formation and role of palladium chalcogenide and other species in Suzuki-Miyaura and Heck C-C coupling reactions catalyzed with palladium(II) complexes of organochalcogen ligands: realities and speculations. Organometallics 2014, 33, 2921-2943. [CrossRef]

38. Dhakshinamoorthy, A.; Asiri, A.M.; Garcia, H. Metal-organic frameworks catalyzed C-C and C-heteroatom coupling reactions. Chem. Soc. Rev. 2015, 44, 1922-1947. [CrossRef] [PubMed]

39. Zhu, Y.; Hosmane, N.S. Nanocatalysis: Recent advances and applications in boron chemistry. Coord. Chem. Rev. 2015, 293-294, 357-367. [CrossRef]

40. Wang, D.; Deraedt, C.; Ruiz, J.; Astruc, D. Magnetic and dendritic catalysts. Acc. Chem. Res. 2015, 48, 1871-1880. [CrossRef] [PubMed]

41. Yao, Y.; Patzig, C.; Hu, Y.; Scott, R.W.J. In Situ X-ray absorption spectroscopic study of Fe@FexOy/Pd and $\mathrm{Fe} @ \mathrm{FexOy} / \mathrm{Cu}$ nanoparticle catalysts prepared by galvanic exchange reactions. J. Phys. Chem. C 2015, 119, 21209-21218. [CrossRef]

42. Wittmann, S.; Majoral, J.-P.; Grass, R.N.; Stark, W.J.; Reiser, O. Carbon coated magnetic nanoparticles as supports in microwave-assisted palladium catalyzed Suzuki-Miyarura coupling. Green Process. Synth. 2012, 1, 275-279.

43. Sun, Z.; Yang, J.; Wang, J.; Li, W.; Kaliaguine, S.; Hou, X.; Deng, Y.; Zhao, D. A versatile designed synthesis of magnetically separable nano-catalysts with well-defined core-shell nanostructures. J. Mater. Chem. A 2014, 2, 6071-6074. [CrossRef]

44. Woo, H.; Lee, K.; Park, J.C.; Park, K.H. Facile synthesis of $\mathrm{Pd} / \mathrm{Fe}_{3} \mathrm{O}_{4} /$ charcoal bifunctional catalyst with high metal loading for high product yields in Suzuki-Miyaura coupling reactions. New J. Chem. 2014, 38, 5626-5632. [CrossRef]

45. Li, Y.; Zhang, Z.; Shen, J.; Ye, M. Hierarchical nanospheres based on Pd nanoparticles dispersed on carbon coated magnetic cores with a mesoporours ceria shell: A highly intergrated multifunctional catalyst. Dalton Trans. 2015, 44, 16592-16601. [CrossRef] [PubMed]

46. Cappelletti, A.L.; Uberman, P.M.; Martín, S.E.; Sateta, M.E.; Troiani, H.E.; Sánchez, R.D.; Carbonio, R.E.; Strumia, M.C. Synthesis, characterization, and nanocatalysis application of core-shell superparamagnetic nanoparticles of $\mathrm{Fe}_{3} \mathrm{O}_{4} @ \mathrm{Pd}$. Aust. J. Chem. 2015, 68, 1492-1501. [CrossRef]

47. Hosseini-Sarvari, M.; Khanivar, A.; Moeini, F. Palladium immobilized on $\mathrm{Fe}_{3} \mathrm{O}_{4} / \mathrm{ZnO}$ nanoparticles: A novel magnetically recyclable catalyst for Suzuki-Miyaura and Heck reactions under ligand-free conditions. J. Iran. Chem. Soc. 2016, 13, 45-53. [CrossRef]

48. Li, Y.; Zhang, Z.; Fan, T.; Li, X.; Dong, P.; Baines, R.; Shen, J.; Ye, M. Magnetic core-shell to yolk-shell structures in palladium-catalyzed Suzuki-Miyaura reactions: Heterogeneous versus homogeneous nature. ChemPlusChem 2016, 81, 564-573. [CrossRef] 
49. Xia, J.; Fu, Y.; He, G.; Sun, X.; Wang, X. Core-shell-like Ni-Pd nanoparticles supported on carbon black as a magnetically separable catalyst for green Suzuki-Miyaura coupling reactions. Appl. Catal. B 2017, 200, 39-46. [CrossRef]

50. Zhang, Q.; Su, H.; Luo, J.; Wei, Y. “Click" magnetic nanoparticle-supported palladium catalyst: A phosphine-free, highly efficient and magnetically recoverable catalyst for Suzuki-Miyaura coupling reactions. Catal. Sci. Technol. 2013, 3, 235-243. [CrossRef]

51. Chaicharoenwimolkul, L.; Chairam, S.; Namkajorn, M.; Khamthip, A.; Kamonsatikul, C.; Tewasekson, U.; Jindabot, S.; Pon-On, W.; Somsook, E. Effect of ferrocene substituents and ferricinium additive on the properties of polyaniline derivatives and catalytic activities of palladium-doped poly(m-ferrocenylaniline)-catalyzed Suzuki-Miyaura cross-coupling reactions. J. Appl. Polym. Sci. 2013, 130, 1489-1497. [CrossRef]

52. Karimi, B.; Mansouri, F.; Vali, H. A highly water-dispersible/magnetically separable palladium catalyst based on $\mathrm{Fe}_{3} \mathrm{O}_{4} @ \mathrm{SiO}_{2}$ anchored TEG-imidazolium ionic liquid for the Suzuki-Miyaura coupling reaction in water. Green Chem. 2014, 16, 2587-2596. [CrossRef]

53. Esmaeilpour, M.; Javidi, J.; Dodeji, F.N.; Hassannezhad, H. $\mathrm{Fe}_{3} \mathrm{O}_{4} @ \mathrm{SiO}_{2}$-polymer-imid-Pd magnetic porous nanosphere as magnetically separable catalyst for Mizoroki-Heck and Suzuki-Miyaura coupling ractions. J. Iran. Chem. Soc. 2014, 11, 1703-1715. [CrossRef]

54. Le, X.; Dong, Z.; Jin, Z.; Wang, Q.; Ma, J. Suzuki-Miyaura cross-coupling reactions catalyzed by efficient and recyclable $\mathrm{Fe}_{3} \mathrm{O}_{4} @ \mathrm{SiO}_{2} @ \mathrm{SiO}_{2}-\mathrm{Pd}(\mathrm{II})$ catalyst. Catal. Commun. 2014, 53, 47-52. [CrossRef]

55. Ghotbinejad, M.; Khosropour, A.R.; Mohammadpoor-Baltork, I.; Moghadam, M.; Tangestaninejad, S.; Mirkhani, V. Ultrasound-assisted C-C coupling reactions catalyzed by unique SPION-A-Pd(EDTA) as a robust nanocatalyst. RSC Adv. 2014, 4, 8590-8596. [CrossRef]

56. Nehlig, E.; Waggeh, B.; Millot, N.; Lalatonne, Y.; Motte, L.; Guénin, E. Immobilized Pd on magnetic nanoparticles bearing proline as a highly efficient and retrievable Suzuki-Miyaura catalyst in aqueous media. Dalton Trans. 2015, 44, 501-505. [CrossRef] [PubMed]

57. Esmaeilpour, M.; Javidi, J. Magnetically-recoverable Schiff Base Complex of $\mathrm{Pd}(\mathrm{II})$ immobilized on $\mathrm{Fe}_{3} \mathrm{O}_{4} @ \mathrm{SiO}_{2}$ nanoparticles: An efficient catalyst for Mizoroki-Heck and Suzuki-Miyaura coupling reactions. J. Chin. Chem. Soc. 2015, 62, 614-626. [CrossRef]

58. Gholinejad, M.; Razeghi, M.; Ghaderi, A.; Biji, P. Palladium supported on phosphinite functionalized $\mathrm{Fe}_{3} \mathrm{O}_{4}$ nanoparticles as a new magnetically separable catalyst for Suzuki-Miyaura coupling reactions in aqueous media. Catal. Sci. Technol. 2016, 6, 3117-3127. [CrossRef]

59. Khakiani, B.A.; Pourshamsian, K.; Veisi, H. A highly stable and efficient magnetically recoverable and reusable Pd nanocatalyst in aqueous media heterogeneously catalyzed Suzuki C-C cross-coupling reactions. Appl. Organometal. Chem. 2015, 29, 259-265. [CrossRef]

60. Azizi, K.; Ghonchepour, E.; Karimi, M.; Heydari, A. Encapsulation of Pd(II) into superparamagnetic nanoparticles grafted with EDTA and their catalytic activity towards reduction of nitroarenes and Suzuki-Miyaura coupling. Appl. Organometal. Chem. 2015, 29, 187-194. [CrossRef]

61. Mowassagh, B.; Takallou, A.; Mobaraki, A. Magnetic nanoparticle-supported Pd(II)-cryptand 22 complex: An efficient and reusable heterogeneous precatalyst in the Suzuki-Miyaura coupling and the formation of aryl-sulfur bonds. J. Mol. Catal. A Chem. 2015, 401, 55-65. [CrossRef]

62. Hoseini, S.J.; Heidari, V.; Nasrabadi, H. Magnetic $\mathrm{Pd} / \mathrm{Fe}_{3} \mathrm{O}_{4} /$ reduced-graphene oxide nanohybrid as an efficient and recoverable catalyst for Suzuki-Miyaura coupling reaction in water. J. Mol. Catal. A Chem. 2015, 396, 90-95. [CrossRef]

63. Wang, Z.; Yu, Y.; Zhang, Y.X.; Li, Z.; Qian, H.; Lin, Z.Y. A magnetically separable palladium catalyst containing a bulky $N$-heterocyclic carbine ligand for the Suzuki-Miyaura reaction. Green Chem. 2015, 17, 413-420. [CrossRef]

64. Ghotbinejad, M.; Khosropour, A.R.; Mohammadpoor-Baltork, I.; Moghadam, M.; Tangestaninejad, S.; Mirkhani, V. SPIONs-bis(NHC)-palladium(II): A novel, powerful and efficient catalyst for Mizoroki-Heck and Suzuki-Miyaura C-C coupling reactions. J. Mol. Catal. A Chem. 2014, 385, 78-84. [CrossRef]

65. Liu, X.; Zhao, X.; Lu, M. A highly water-dispersible and magnetically separable palladium catalyst based on functionalized poly(ethylene glycol)-supported iminophosphine for Suzuki-Miyaura coupling in water. Appl. Organometal. Chem. 2015, 29, 419-424. [CrossRef] 
66. Azadi, G.; Ghorbani-Choghamarani, A. Immobilized palladium on modified magnetic nanoparticles and study of its catalytic activity in Suzuki-Miyaura C-C coupling reaction. Appl. Organometal. Chem. 2016, 30, 360-366. [CrossRef]

67. Martinez-Olid, F.; Andrés, R.; de Jesus, E.; Flores, J.C.; Gómez-Sal, P.; Heuze, K.; Vellutini, L. Magnetically recoverable catalysts base don mono- or bis-(NHC) complexes of palladium for the Suzuki-Miyaura reaction in aqueous media: Two NHC-Pd linkages are better than one. Dalton Trans. 2016, 45, 11633-11638. [CrossRef] [PubMed]

68. Salemi, H.; Kaboudin, B.; Kazemi, F.; Yokomatsu, T. Highly water-dispersible magnetite nanoparticle supported-palladium- $\beta$-cyclodextrin as an efficient catalyst for Suzuki-Miyaura and Sonogashira coupliong reactions. RSC Adv. 2016, 6, 52656-52664. [CrossRef]

69. Ghorbani-Vaghei, R.; Hemmati, S.; Hekmati, M. Pd immobilized on modified magnetic $\mathrm{Fe}_{3} \mathrm{O}_{4}$ nanoparticles: Magnetically recoverable and reusable Pd nanocatalyst for Suzuki-Miyaura coupling reactions and Ullmann-type N-arylation of indoles. J. Chem. Sci. 2016, 128, 1157-1162. [CrossRef]

70. Hajipour, A.R.; Tadayoni, N.S.; Khorsandi, Z. Magnetic iron oxide nanoparticles-N-heterocyclic carbine-palladium(II): A new, efficient and robust recyclable catalyst for Mizoroki-Heck and Suzuki-Miyaura coupling reactions. Appl. Organometal. Chem. 2016, 30, 590-595. [CrossRef]

71. Dubey, A.V.; Kumar, A.V. A biomimetic magnetically recoverable palladium nanocatalyst for the Suzuki cross-coupling reaction. RSC Adv. 2016, 6, 46864-46870. [CrossRef]

72. Phan, N.T.S.; Van Der Sluys, M.; Jones, C.W. On the nature of the active species in palladium catalyzed Mizoroki-Heck and Suzuki-Miyaura couplings-Homogeneous or heterogeneous catalysis, a critical review. Adv. Synth. Catal. 2006, 348, 609-679. [CrossRef]

(C) 2017 by the author; licensee MDPI, Basel, Switzerland. This article is an open access article distributed under the terms and conditions of the Creative Commons Attribution (CC BY) license (http:/ / creativecommons.org/licenses/by/4.0/). 